Working Paper 385

\title{
INTERNATIONAL TRADE, R\&D SPILLOVERS AND PRODUCTIVITY: EVIDENCE FROM INDIAN MANUFACTURING INDUSTRY
}

\author{
M. Parameswaran
}

June 2007 
Working Papers published since August 1997 (WP 279 onwards) can be downloaded from the Centre's website (www.cds.edu) 


\section{INTERNATIONAL TRADE, R\&D SPILLOVERS AND \\ PRODUCTIVITY: EVIDENCE FROM INDIAN \\ MANUFACTURING INDUSTRY}

\section{Parameswaran}

June 2007

The author would like to thank K. Pushpangadan, Sunil Mani, Thomas Ziesemer, Pierre Mohnen, and Joel Horowitz for helpful comments and suggestions; also the participants to the seminar presentations at Centre for Development Studies, Trivandrum, India, United Nations Institute for New Technologies at Maastricht, The Netherlands and South and South East Asian Econometric Society Meeting at Chennai India. The usual disclaimers apply. 


\begin{abstract}
This paper examines the effect of trade facilitated R\&D spillovers on the productivity of manufacturing firms in India. Though developing countries are considered as the major beneficiaries of trade facilitated R\&D spillovers, detailed empirical investigations in their context are lacking. The paper distinguishes R\&D spillovers into two types and examines their effect on productivity. It also considers the intersectoral variation in productivity effect and the importance of firms' investment in R\&D, imported technology and plant and machinery in enhancing the effect on productivity. The paper uses firm level panel data and an improved estimation method. It shows that R\&D spillovers have a significant effect on productivity and there exists intersectoral variation with greater contribution to productivity in technology intensive industries. The paper also shows that firms' investment in R\&D and plant and machinery are enhancing the productivity effect of R\&D spillovers.
\end{abstract}

Keywords: R\&D Spillover, trade, manufacturing industry, productivity

JEL Classification: F43, L6, O33. 


\section{Introduction}

International trade is considered as an important channel of diffusion of technological knowledge among countries (Grossman and Helpman 1991 and Keller 2004). As only a handful of rich countries account for world's creation of new technologies, developing countries are considered as the major beneficiaries of the trade facilitated technology spillovers ${ }^{1}$. This point has been used to motivate the case for trade liberalization in developing countries ${ }^{2}$. Income convergence among countries, particularly among trading countries, is the another possible consequence of trade facilitated technology spillovers $^{3}$, as productivity differences account for a larger part of the cross-country variation in income and technology is the key determinant of productivity $^{4}$. These anticipated benefits of trade facilitated technology spillovers, however, crucially depends on its strength as well as on whether it is an inevitable consequence of trade or not. Obviously, these questions are related to the empirics of technology spillovers and therefore, one has to look into the empirical investigations. However, empirical studies examining the contribution of trade facilitated technology spillovers to productivity in the context of developing

1 For instance, G-7 countries accounted for about 84 percent of the world's research and development (R\&D) spending in 1995 (Keller, 2004).

2 See Kruger (1998).

3 Ben-David and Loewy (1998) considering the cross-country income convergence using this idea.

$4 \quad$ See Prescott (1998). 
countries are very rare. Studies in the context of developed countries include Coe and Helpman (1995), Xu and Wang (1999), Keller (2000), Funk (2001) and Olarreaga and Schiff (2005). These studies find significant productivity effect of trade facilitated technology spillovers. One study examining it in the context of developing countries is Coe et al. (1997). It shows significant productivity effect of trade facilitated technology spillovers from 22 developed countries in 77 developing countries.

All these studies use country level or industry level data ${ }^{5}$. It has been noted in the literature that use of aggregate level data induces an upward bias in the estimated coefficient of the spillover variable. To quote, Keller (2004, p. 778) "the higher is the level of aggregation the stronger tends to be the evidence for externality and learning effect". Therefore, studies using micro level data are suggested to be quite fruitful ${ }^{6}$. They can not only capture the heterogeneity found even in the narrowly defined industries, but also give detailed insights into the aspects such as intersectoral differences in the effect on productivity and the importance of firm's own effort in absorbing technology spillovers. This paper goes in this direction. It examines the effect of trade facilitated $R \& D$ spillovers on the productivity of manufacturing firms in India. We distinguish trade related R\&D spillovers into two types and examine their effect on productivity. Further, the paper also considers the intersectoral variation in the effect on productivity and the importance of firms' investment in $R \& D$, imported technology and plant and machinery in enhancing the productivity effect of R\&D spillovers.

$5 \quad$ Keller (2000) is the only study using industry level data.

6 Apart from the aggregation problem, studies based on aggregate country level data also suffer from dubious quality of data. For more on this see Heston (1994) 
The rest of the paper is organised in the remaining four sections. Section two presents the theoretical literature on trade facilitated R\&D spillovers and third section explains methodology, data and construction of variables. The fourth section discusses estimation and results and the last one concludes the paper.

\section{Types of R\&D spillovers and the role of trade}

R\&D spillover means spillover of technological knowledge generated through firms' investment in R\&D. It enhances receiving firm's productivity ${ }^{7}$. R\&D spillovers can be distinguished into two types: (1) rent spillovers, and (2) knowledge spillovers (Griliches 1992 and 1979). Rent spillovers take place through the purchase of capital goods embodying better technology. By investing in $\mathrm{R} \& \mathrm{D}$, firms in the capital goods sector produce machines and equipment of better quality. The $\mathrm{R} \& \mathrm{D}$ investment in the machine producing sector can increase the productivity of firms who purchase these better quality machines. However, this type of spillovers and the subsequent productivity growth in buyer industries would occur only when the purchase of R\&D intensive goods takes place at a price less than their full 'quality price'. In other words, it takes place only when the innovating firms fail to appropriate the full improvement in the quality of the machine in terms of higher price $^{8}$. It is, therefore, called 'rent spillovers'.

Knowledge spillovers take place when the ideas generated by one firm are utilised by other firms. The distinctive feature of knowledge

7 For a discussion on the features of technological knowledge, namely non-rival and non-excludable character, that generate spillovers see Grossman and Helpman (1991).

8 The extent of rent spillovers depends on the market structure of the machinery producing industry. If it is a competitive environment, producers may find it difficult to capture the whole improvement in the quality of the product through higher price. On the other hand, a perfectly discriminating monopolist may capture all the improvement in the quality through higher price. For more on this see Griliches (1979). 
spillovers compared to rent spillovers is that they are not tied to the purchase of any input whose price undervalues its quality. Several channels, such as personal interaction, familiarity with technologically superior products, information about patents, publication in scientific journals and participation in conferences, can facilitate knowledge spillovers.

Trade facilitates both types of spillovers among the trading countries, particularly from the technology leader countries to the developing countries. Import of capital goods from the research intensive countries can transfer the benefits of R\&D to the importing countries ${ }^{9}$. Trade can facilitate knowledge spillovers by facilitating the interaction of developing country producers with developed country producers, buyers and products (Grossman and Helpman 1991). For instance, import of final manufactured products from the developed to developing countries allows the latter country producers to get familiar with technologically superior products. This familiarity gives them useful insights and ideas to improve their products. Similarly, exports to technological leader countries can also facilitate knowledge spillovers. Exporting gives a chance for the developing country firms to interact with their foreign buyers and learn about new ways to improve their product and production process ${ }^{10}$. Commercial success of firms importing foreign products depends on the quality and price of these products. Importers in developed countries, therefore, usually inform foreign producers about new technology or possible alternations to the product to make it meet the demand in a better way. Further, to sustain exports to developed countries, firms have to keep up with the technological progress taking place in the respective product line in their

9 Eaton and Kortum (2001) points out that high R\&D intensive countries are also the major producers and net exporters of capital equipment in the world; indicating the possibility of larger gain for the developing countries through rent spillovers.

10 For instance, the case studies by Eagan and Mody (1992) and Schmitz and Knorringa (2000) show that foreign purchasers are an important source of technological information for the developing country producers. 
export markets. Hence, exporting can have the effect of directing the producers' global search for knowledge to countries to which they export. It is postulated that the extent of knowledge spillovers through trade between any two countries is an increasing function of the intensity of their commercial interaction, which in turn increases with the volume of their bilateral trade. Grossman and Helpman (1991, p.166-7) brings out this clearly.

It is plausible to suppose that foreign contribution to the local knowledge stock increases with the number of commercial interactions between domestic and foreign agents. That is, we may assume that international trade in tangible commodities facilitates the exchange of intangible ideas...It seems reasonable to assume therefore that the extent of the spillovers between any two countries increase with the volume of their bilateral trade.

It has, however, been noted in the literature that $R \& D$ spillover is not a passive process, it is an active process in the sense that deliberate efforts on the part of the firm are necessary for its efficient absorption (Keller 2004). This is because of the tacitness and sophisticated nature of knowledge and therefore, its assimilation requires certain capabilities on the part of the firm. The firm can achieve these capabilities through investment in R\&D and plant and machinery and employment of skilled labours (Cohen and Levinthal 1989). A related aspect is the intersectoral variation in the productivity effect of spillovers, particularly between technology intensive and low technology sectors. It is difficult to say $a$ priori whether productivity effect is higher in technology intensive industries or not. It depends upon the relative importance of complexity of knowledge and the opportunities for learning in these industries. It is possible that productivity effect can be lower due to the tacitness and sophistication of knowledge in technology intensive industries. On the other hand, because of the greater opportunities for learning existing in these industries the effect on productivity can be higher. 


\section{R\&D Spillovers and Productivity: Methodology}

This study uses production function approach, which is widely used to assess the contribution of R\&D and other technological investments to productivity. A firm is assumed to produce output Q using a bundle of traditional inputs $\mathrm{X}$, such as capital and labour, subject to the state of technology T. Improvement in the state of technology increases the productivity of traditional factors of production. Manufacturing firms in India can improve their level of technology through R\&D investment, purchase of capital goods embodying better technology from foreign and domestic sources, absorption of trade facilitated knowledge spillovers and import of disembodied technology through licensing. The import of disembodied technology involves purchase of designs, blue prints and technical assistance by paying lumpsum amount or royalty.

One of our objectives is to examine the productivity effect of rent spillovers through machinery import. Given the available data, it is not possible to measure the technological content of imported machinery. Therefore, the study adopts an indirect approach to draw inference on the existence of rent spillovers. It is assumed that recently purchased machinery contains more technology per unit of money invested than old ones. If this is valid, the share of capital stock made up of recent investment in plant and machinery in the total capital stock will have significant positive effect on productivity ${ }^{11}$. On this basis, shares of two types of capital stock made up recent investment in plant and machinery have been included in the production function as arguments. The first

11 If firms maximise profit, producers would allocate investment between various types of capital goods such that ex ante rates of return are equal. In such a situation, there is no reason to expect that the composition of capital stock will have an effect on productivity. On the other hand, if, ex post, marginal product of new capital stock (or imported) is larger than that of old (or domestic), the share of new capital stock (or imported) will have a positive effect on productivity (Brendt and Morrison 1995). 
type consists of capital goods purchased from domestic sources and the second is constructed from imported machinery ${ }^{12}$. This specification also allows us to test whether imported machinery has greater effect on productivity compared to that of the machinery purchased from domestic sources.

The production function, which is of Cobb-Douglas form, with technology variables ${ }^{13}$ for the $i^{\text {th }}$ firm in year $t$ is:

$$
\begin{gathered}
q_{i t}=b_{0}+b_{c} c_{i t}+b_{l} l_{i t}+b_{m} m_{i t}+b_{e} e_{i t}+b_{s d c g} s d c g_{i t}+b_{s i c g} s i c g_{i t}+b_{p k} p k_{i t}+ \\
b_{k} k_{i t}+b_{s k} s k_{i t}+\varepsilon_{i t}
\end{gathered}
$$

where $q$ denotes $\log$ of output, $c$ is $\log$ of fixed capital stock, $l$ is $\log$ of labour hours, $m$ is $\log$ of raw materials, $e$ is $\log$ of energy, $s d c g$ is $\log$ share of recent investments in capital goods purchased from domestic sources in the total capital stock, sicg is the log share of recently imported capital goods in the total capital stock, $p k$ is the log of disembodied technology import stock, $s k$ is the log of trade related knowledge spillover stock, and $\varepsilon$ is the error term.

\section{Data}

The basic database of the study is the firm level panel data of 19 industries in International Standard Industrial Classification revision 2 (ISIC rev.2) for the period 1988-89 to 2000-2001, obtained from the Centre for Monitoring Indian Economy's (CMIE) electronic database

12 Though we are concerned with $R \& D$ spillovers through imported machinery, it should be noted that this approach would capture all the quality improvement in the new capital goods (compared to that of old capital goods) that is not appropriated by the machinery producer through higher price, irrespective of the source of improvement in quality.

13 Since some technology variables can take zero value, 1 has been added to them as in Raut (1995) and Hasan (2002) to avoid the problem of having to take log of zero values. 
PROWESS. After removing observations having zero values for output, wages and salaries, capital stock, raw materials and energy as well as observations not having continuous time series (which is necessary to construct stock variables), the sample consists of 17760 observations on 2101 firms ${ }^{14}$. The firm level dataset provides information on a number of variables, including expenditure on $R \& D$ and import of capital goods and disembodied technology.

Other data sets we use include: (1) industry level R\&D expenditure of fifteen OECD countries for the period 1978 to 2000, obtained from the Analytical Business Enterprise Research and Development Database (ANBERD) of OECD; (2) industry level information from Annual Survey of Industries (ASI) of India, and (3) data on bilateral trade of India in manufactures with fifteen developed OECD countries, obtained from Trade and Production database of the World Bank ${ }^{15}$. For the list of industry covered by the study, Table 1 may be referred to, which also provides classification of industries into two sectors that will be discussed later $^{16}$. We take fifteen OECD countries as the source of trade related knowledge spillovers into Indian manufacturing industry ${ }^{17}$. These countries account for around 50 per cent of trade in manufactures of India during the period of study.

\section{Construction of variables}

All the variables in the production function are in 1993-94 prices, obtained by deflating values reported in current prices using appropriate price

14 Since it is not mandatory for the firms to report to the data collecting agency, entry or exit of firms from the data set do not indicate firms' actual entry into or exit from production.

15 More details on this database can be seen in Nicita and Olarreaga (2001).

16 R\&D statistics of OECD countries are given in the ISIC rev 2 classification and we reclassified all other date sets into this classification.

17 These countries are: Australia, Canada, Denmark, Finland, France, Germany, Ireland, Italy, Japan, the Netherlands, Norway, Spain, Sweden, United Kingdom and United States. 
indices collected from "Index Numbers of Wholesale Prices in India, base 1993-94 = 100" published by the Economic Adviser Ministry of Commerce and Industry, Government of India. The specific details on the construction of each variable are given below ${ }^{18}$.

Output (Q): The output series are obtained by deflating reported nominal value of output. We have used more disaggregated level industry price indices (than that reported in Table 1), for deflation in order to mitigate discrepancy between firm level price deflator and industry level price deflator $^{19}$.

Raw materials (M): It is obtained by deflating the reported cost of raw materials consumed using raw material price indices. Raw material price index for each industry (this also at more disaggregated level) are constructed using weights obtained from Input-Output Transaction Table of India for 1993-94, published by the Central Statistical Organisation (CSO) and appropriate price indices are collected from Index Numbers of Wholesale Prices in India, base 1993-94=100.

Capital (C): The database reports Gross Fixed Asset (GFA) of the firm in historical cost. Capital stock is constructed using perpetual inventory method by taking 1995-96 as the benchmark year. For this, we have converted the reported GFA of 1995-96 into replacement cost on the basis of a revaluation factor computed using the procedures given in Srivastava $(1996)^{20}$. We use gross fixed asset rather than the net fixed

18 In this paper variables in log form are denoted by their name in lower case letters.

19 This deflation procedure is more appropriate in perfectly competitive market situations, where the law of one price exists and hence all firms face same price. In the present context, there is always a discrepancy between the firm level price deflator and industry level price deflator. Since we do not have data on firm level price deflator, we are not in a position to address this issue.

20 Parameswaran (2002) also reports the algebraic expression used to compute the revaluation factor. 
asset, as the construction of net fixed asset needs information on the economic rate of depreciation of assets, which is not available for the Indian manufacturing industry ${ }^{21}$.

Labour (L): Labour input is measured in terms of labour hours. It is constructed by dividing the reported total wage bill of the firm by the average wage per hour obtained from the corresponding industry of ASI (this is also done at a more disaggregated level). If the variation in the wage bill across firms also reflects the variation in the quality of labour they employ, our measure would also capture the quality aspect of labour input.

Energy (E) : It is constructed by deflating the reported energy cost by an energy price index constructed using weights obtained from the InputOutput Transaction Table of India for 1993-94 and appropriate price indices.

$\underline{\text { R\&D Capital Stock }(\mathrm{K})}$ : The stock of technological knowledge generated through R\&D investment is approximated by the R\&D capital stock ${ }^{22}$. It is constructed from the $R \& D$ investment flows using perpetual inventory method, assuming that $\mathrm{R} \& \mathrm{D}$ investment affects productivity with a lag of one year. R\&D capital stock of $i^{t h}$ firm in year $t$ can be written as follows.

$$
K_{i t}=(1-\delta) K_{i t-1}+R D_{i t-1}
$$

where $\mathrm{RD}$ is the real $\mathrm{R} \& \mathrm{D}$ expenditure in the year $t-1$ and $\delta$ is the rate of depreciation of technological knowledge, assumed to be 15

21 In this context it is worth citing Dennison (1967), who argues that correct measure of capital stock falls somewhere between gross and net and therefore advocates for the use of weighted average of the two with higher weight for the gross asset as the true value is expected to be closer to it.

22 Measurement of the knowledge stock generated through R\&D investment is quite difficult and involves many conceptual and measurement issues, for more details see Griliches (1979). 
percent ${ }^{23}$. The real $R \& D$ expenditure is obtained from the reported nominal expenditure using an $R \& D$ deflator, which is a weighted average of the capital and wage deflators in the manufacturing industry. The weights are the average shares of current and capital expenditure in the total $R \& D$ expenditure ${ }^{24}$. Implementation of the perpetual inventory method needs information on the initial year value of $K_{i t}$ for each firm. Since we do not have information on firms' pre sample years' R\&D investment, this has been approximated in the following way. In the case of firms not reporting any $R \& D$ expenditure in the first three years of their time series, we have assumed that they did not have any R\&D investment during the pre sample years. This is based on the presumption that when a firm is not reporting any $R \& D$ expenditure consecutively for three years the probability of it having previous $R \& D$ investment is very low.

Construction of the initial year R\&D stock of firms that report $R \& D$ expenditure during the first three years of their time series requires information on the number of pre sample years of R\&D investment and its growth rate. If the number of pre sample years of $R \& D$ investment is $s$, the rate of depreciation is $\delta$ and the growth rate of pre sample R\&D investment is $g$, the initial year R\&D stock $K_{i t}$ can be expressed as follows,

$$
K_{i t}=R D_{t-1} \sum_{a=0}^{s}\left(\frac{(1-\delta)}{(1+g)}\right)^{a}
$$

The above method is used to compute the initial year R\&D capital stock by approximating $g$ by the growth rate of real R\&D expenditure

23 One year lag in the effect of $R \& D$ and 15 per cent depreciation rate are taken on the basis of the previous studies in the context of India (see Raut 1995, Basant and Fikkert 1996 and Hasan 2002).

$24 \quad$ Here it is assumed that R\&D current expenditure mainly includes wage bill of the R\&D employees and capital expenditure includes the purchase of equipment required by the $R \& D$ unit. The database reports the current and capital expenditure on R\&D separately. 
per R\&D unit during the period $1985-86$ to $1996-97$ and $R D_{t-1}$ by the average $R \& D$ expenditure of the firm during the first three years. We take an average, because it is expected to give a better estimate of the $R \& D$ expenditure pattern of the firm ${ }^{25}$. The number of pre sample years of $R \& D$ investment is assumed to be five.

Disembodied Technology Import Stock (PK): The disembodied technology import stock $(\mathrm{PK})$ is constructed from the flows of technology payments using perpetual inventory method and assuming one year lag in its effect on productivity, as shown below.

$$
P K_{i t}=(1-\delta) P K_{i t-1}+P_{i t-1}
$$

Where $P_{i t}$ is the real expenditure on disembodied technology import. Following the previous studies in the context of India, it is assumed that rate of depreciation $\delta$ is 15 percent. Since USA is the largest seller of technology to India, the real expenditure is obtained by deflating the nominal expenditure using US R\&D deflator after making adjustment for the change in rupee-dollar exchange rate. The major problem here also is to arrive at the initial year stock of the firm. Here, we follow the procedure adopted in Basant and Fikkert (1996). This involves two basic steps. First, identification of the years in which the firm entered into a licensing agreement with a foreign firm during the period starting from 1982-83 onwards ${ }^{26}$. For this we used the publication Foreign Collaborations in India, published by the Council for Scientific and Industrial Research, India. In the second step, using sample information, an industry level average of the ratio of technology expenditure to sales was estimated for the initial year of the firm that imported technology in the past. These ratios were then multiplied by the firm's initial year sales to get an estimate of per year technology

26 We have considered the past foreign technology collaborations of firms from 1982-83 onwards to reduce the enormous amount of work involved due to the large number of firms in our sample. 
flows, assuming that technology flows from a collaboration agreement last for four years, as revealed in Kapur (1989, cited in Basant and Fikkert 1996). These payments are then deflated and depreciated to obtain technology import stock of the initial year.

Stock of recent investment in imported capital goods (SRICG): The reported expenditure on capital goods import is deflated using the unit value index of the imported capital goods with base 1993-94 = 100 to arrive at real investment in imported capital goods $\left(I^{M}\right)$. The unit value indices are collected from the Statistical Abstract of India, published by the Central Statistical Organisation, New Delhi. Recent five years' investments have been used to construct the stock of recent investment in imported capital goods (SRICG), as given below 27 .

$$
S R I C G_{i t}=\sum_{s=0}^{4} I_{i t-s}^{M}
$$

The initial year stock of recent investment in imported capital goods (SRICG) is estimated using the following procedure. Let SRICG $G_{i o}$ denote the initial year stock of recently imported capital goods, it can be written as follows,

$$
\operatorname{SRICG}_{i 0}=I_{i 0}^{I M} \sum_{s=0}^{4}\left(\frac{1}{(1+g)}\right)^{s}
$$

Where $I_{i 0}^{I M}$ is the initial year real investment in imported capital goods and $g$ is the growth rate of real investment in imported capital goods. $I_{i 0}^{I M}$ is approximated using an average of firm's investment in imported capital goods during the first five years. An average is taken, instead of initial year value, because it is likely to be a more representative 
indicator of firm's pattern of investment. The growth rate $g$ is approximated by the growth rate of real capital formation through imported capital goods.

The share of the recent investment in imported capital stock (SICG) in the total capital stock is SRICG/C.

Stock of Recent Investment in Domestically Purchased Capital Goods (SRDCG): The stock of recent investment in the capital goods purchased from domestic sources is obtained from the stock of recent investment in plant and machinery after subtracting the stock of recent investment in the imported capital goods, as given below.

$$
S R D C G_{i t}=\sum_{s=0}^{4} I_{i t-s}-S R I C G_{i t}
$$

Where $I$ is the real investment in plant and machinery. The initial year value of SRDCG is estimated using a procedure similar to the estimation of the initial year SRICG by approximating ' $\mathrm{g}$ ' by the growth rate of real investment in plant and machinery in manufacturing. The share of the capital stock made up of recent investments in capital goods purchased from domestic sources in the total capital stock (SDCG) is defined as SRDCG/C.

Trade Related Knowledge Spillover Stock (SK): This variable is constructed on the basis of the conceptual and methodological framework suggested in Griliches (1992 and 1979). In this, the extent of knowledge spillovers among industries depends on the economic and technological distance between them. If technologically similar industries have closer economic interactions knowledge spillovers among them would be higher. Following the theoretical literature, we assume that the amount of knowledge spillovers an Indian industry receives from the same industry operating in an OECD country increases with the extent of trade interaction with that country and with the knowledge stock of the foreign 
industry. The available data permit us only to construct an industry level variable to capture trade related knowledge spillovers. Hence in what follows the subscript $i$ denotes the industry. The extent of trade interaction of $i^{\text {th }}$ domestic industry with $j^{\text {th }}$ country is measured by its trade intensity with that country. It is also assumed that knowledge obtained through the interaction in the last year affects current year productivity. Let $S K_{i t}$ be the spillover knowledge stock received by the $i^{t h}$ Indian industry from the same industry operating in fifteen OECD countries, $X_{i t}$ be the total export of $i^{\text {th }}$ Indian industry to fifteen OECD countries, $M_{i t}$ be the total import of $i^{t h}$ industry's products from same countries and $Q_{i t}$ is the output of Indian industry, $F K_{i j t}$ is the R\&D capital stock of the $i^{\text {th }}$ industry in country $j$, Xijt denotes export of the ith Indian industry to $j^{\text {th }}$ country and $M_{i j t}$ is the import of $i^{\text {th }}$ industry's products from country $j$. Now we can write $S K_{i t}$ as follows.

$$
S K_{i t}=\left(\frac{\left(X_{i t-1}+M_{i t-1}\right)}{Q_{i t-1}}\right)\left(\sum_{\mathrm{j}=1}^{15} w_{i j t-1} F K_{i j t-s}\right), s=1,2,3 .
$$

Where $w_{i j t-1}$ is defined as,

$$
w_{i j t-1}=\frac{M_{i j t-1}+X_{i j t-1}}{X_{i t-1}+M_{i t-1}}
$$

The weighting function $w_{i j t}$ is a measure of extent of trade interaction of $i^{\text {th }}$ Indian industry with $j^{\text {th }}$ country ${ }^{28}$. It gets a higher value if the trade interaction through export and import is higher and can be considered as the probability of obtaining knowledge spillovers through trade. Multiplying the weighted sum with trade intensity of the industry 
is to adjust for the differences in the trade openness of industries ${ }^{29}$. The various values $s$ takes in the above expression indicate different assumptions about the lag length in the effect of foreign $R \& D$ on domestic productivity. It seems reasonable to assume that firms in India get information about new products or processes through trade interaction only after these products or processes become to some extent standardised at least in the developed countries. Since we do not have any clear idea about the time lag involved in the process of $R \& D$ investment, invention and innovation, we construct three trade related knowledge spillover stock that respectively assume one, two and three years lag in the effect of foreign $\mathrm{R} \& \mathrm{D}$ on domestic productivity.

The foreign R\&D capital stocks (FK) are constructed using the industry level R\&D expenditure data of fifteen OECD countries collected from Analytical Business Enterprise Research and Development Database (ANBERD). The $\mathrm{R} \& \mathrm{D}$ expenditure in this database is reported in current purchasing power parity (PPP) US $\$$. The real R\&D expenditure series is constructed using the US R\&D deflator obtained from the same database. Perpetual inventory method is used to construct foreign R\&D capital stock, assuming a rate of depreciation of 15 percent. The initial year $R \& D$ stocks are estimated using the procedure that we used to estimate the initial year R\&D stock of the firm with the assumption that that industry has infinite years of R\&D experience. In this, historical growth rate of $R \& D$ expenditure is approximated by the growth rate of real $R \& D$ expenditure during the whole period. The foreign $R \& D$ stocks are constructed from 1980 onwards and therefore, errors in the initial year stock estimation can have only a negligible influence on the R \& D stock estimates of the period of study.

The need of this adjustment can be explained using the following simple example. Consider two industries, 1 and 2 and assume that each industry is producing 1000 units of output. Industry one exports 10 units of output; five units to country A and five units to country B. Industry two exports 900 units; 450 units to country A and 450 units to country B. In this case the value of the weighing function $\mathrm{w}_{1 \mathrm{~A}}, \mathrm{w}_{1 \mathrm{~B}}, \mathrm{w}_{2 \mathrm{~A}}$ and $\mathrm{w}_{2 \mathrm{~B}}$ are all equal to 0.50 . However, the involvement of industry two in foreign trade is higher and therefore trade related knowledge spillovers can have wider (hence higher) effect in the industry two. 


\section{Classification of Industries}

Productivity effect of R\&D spillovers can vary among sectors, particularly between technology intensive and low technology industries. This is also true for other types of technological investments like $R \& D$ because of the intersectoral variation in the factors like technological complexity and innovation opportunities. Analysis of this aspect needs classification of industries on the basis of their technological intensity. However, classifying industries on the basis of their technological intensity is a quite difficult task because no single objective criterion is available for this purpose and hence any classification involves some amount of arbitrariness. Therefore, the present study follows previous ones while classifying industries into technology intensive and low technology industries as given in Table 1 . The set of technology intensive industries in the table corresponds to that compiled by two recent studies, namely Connolly (2003) and Hasan (2002). Connolly and Hasan respectively compile a set technology intensive products and industries in a context similar to the present study.

\section{Table 1. Classification of Industries}

\begin{tabular}{|l|l|l|}
\hline \multicolumn{2}{|c|}{ Technology Intensive Industries } & Low Technology Industries \\
\hline 1 & Chemicals, excluding drugs & Food, Beverages \& Tobacco \\
\hline 2 & Drugs and Medicine & Textiles, Apparel \& Leather \\
\hline 3 & Non electrical Machinery & Wood Products \& Furniture \\
\hline 4 & $\begin{array}{l}\text { Electrical Machinery excl. } \\
\text { Communication equipment }\end{array}$ & Paper, paper products \& Printing \\
\hline 5 & $\begin{array}{l}\text { Radio, TV \& Communication } \\
\text { Equipment }\end{array}$ & Petroleum Refineries and Products \\
\hline 6 & $\begin{array}{l}\text { Office Accounting and } \\
\text { Computing Machinery }\end{array}$ & Rubber \& Plastic Products \\
\hline 7 & Motor Vehicles & Non metallic Mineral Products \\
\hline 8 & Other Transport Equipment & Basic metals - Iron \& Steel \\
\hline 9 & $\begin{array}{l}\text { Professional goods and } \\
\text { Scientific instruments. }\end{array}$ & Non ferrous Metals \\
\hline 10 & Metal Products & \\
\hline
\end{tabular}




\section{Estimation and Results}

\section{Estimation:}

We use the semi-parametric methodology of Olley and Pack (1996) as improved upon by Levinsohn and Petrin (2003) to get consistent estimates of the production function (1) in the presence of endogeneity of inputs ${ }^{30}$. It is briefly explained below. Writing the production function as,

$$
\begin{aligned}
q_{i t}= & b_{0}+b_{c} c_{i t}+b_{l} l_{i t}+b_{m} m_{i t}+b_{e} e_{i t}+b_{s d c g} s d c g_{i t}+b_{s i c g} s_{i c g_{i t}}+b_{p k} p k_{i t}+ \\
& b_{k} k_{i t}+b_{s k} s k_{i t}+\omega_{i t}+\eta_{i t}
\end{aligned}
$$

where the error term $\varepsilon_{i t}$ in (1) has been decomposed into two components $\omega_{i t}+\eta_{i t} . \omega_{i t}$ is the firm specific productivity term not accounted by the explanatory variables and $\eta_{i t}$ is a pure random error term. The key point is that $\omega_{i t}$ is observable to the firm and not to the econometrician and enters into firm's input demand function, making OLS estimates inconsistent. In the semi-parametric estimation, it is assumed that firm's raw material demand function $m_{i t}=m_{t}\left(\omega_{i t}, c_{i t}\right)$ is monotonically increasing in productivity, conditional on its capital stock. Inverse of the raw material demand function $\omega_{i t}=\omega_{t}\left(m_{i t}, c_{i t}\right)$ depends only on the observable variables $c_{i t}$ and $m_{i t}$. Rewriting (2) in the following partially linear form,

$$
\begin{gathered}
q_{i t}=b_{l} l_{i t}+b_{e} e_{i t}+b_{s d c g} s d c g_{i t}+b_{s i c g} s i c g_{i t}+b_{p k} p k_{i t}+b_{k} k_{i t}+b_{s k} s k_{i t}+\phi_{t}\left(m_{i t} c_{i t}\right)+\eta_{i t} \\
\text { where } \phi_{t}\left(m_{i t}, c_{i t}\right)=b_{0}+b_{c} c_{i t}+b_{m} m_{i t}+\omega_{t}\left(m_{i t}, c_{i t}\right)
\end{gathered}
$$

Estimation is done in two stages. In the first stage, as the error term in (3) $\eta_{i t}$ is not correlated with the inputs, all coefficients except $b_{c}$ methods like instrumental variable. Further details on this can be seen in Griliches and Mairesse (1998). 
and $b_{m}$ are estimated by including $\phi_{t}($.$) in the estimation routine { }^{31}$. In this $\phi_{t}($.$) is approximated by a third order polynomial with full set of$ interactions. It is also allowed to be different in the three sub-periods of the sample, $1989-90$ to $1992-93,1993-94$ to $1996-97$, and 1997-98 to 2000-01, corresponding to the three distinct growth phases of Indian manufacturing industry. Since capital and raw materials enters $\phi_{t}($.$) in$ two ways, a complete model is used to identify the $b_{c}$ and $b_{m}$. In the second stage, $\omega_{i t}$ is assumed to follow first order Markov process $\omega_{i t}=E\left[\omega_{i t} \mid \omega_{i t-1}\right]+\xi_{i t}$, where $\xi_{i t}$ is the innovation in productivity over last period's expectation. We use two moment conditions to identify $b_{c}$ and $b_{m}$. The moment condition to identify $b_{c}$, which assumes that $c_{i t}$ does not respond to $\xi_{i t}$, is:

$$
E\left[\left(\xi_{i t}+\eta_{i t}\right) c_{i t}\right]=E\left[\xi_{i t} c_{i t}\right]=0
$$

The second moment condition to identify $b_{m}$, which is based on the fact that last period's raw material choice is uncorrelated with $\xi_{i t}$, is 32

$$
E\left[\left(\xi_{i t}+\eta_{i t}\right) m_{i t-1}\right]=E\left[\xi_{i t} m_{i t-1}\right]=0
$$

The residuals used in the moment conditions (4) and (5) are given by:

$$
\begin{aligned}
\xi_{i t} \hat{+} \eta_{i t}\left(b^{*}\right) & =q_{i t}-\hat{b}_{l} l_{i t}-\hat{b}_{e} e_{i t}-\hat{b}_{s d c g} s d c g_{i t}-\hat{b}_{s i c g} \operatorname{sicg} g_{i t} \\
& -\hat{b}_{p k} p k_{i t}-\hat{b}_{k} k_{i t}-\hat{b}_{s k} s k_{i t}-b_{c}^{*} c_{i t}-b_{m}^{*} m_{i t}-E\left[\omega_{i t} \hat{\mid} \omega_{i t-1}\right]
\end{aligned}
$$

31 The production function is also estimated using energy as the proxy and these estimates are similar to those obtained using raw material as proxy. These estimates are available from the author.

$32 m_{i t-1}$ can identify $b_{m}$ in this moment condition since it is highly correlated with $m_{i t}$ due to e.g. size correlation over time because of irreversibility of in capital investment and / or persistence in productivity under Markov process. 
where the residuals are explicitly expressed as a function of two parameters $b^{*}=\left(b_{c}^{*}, b_{m}^{*}\right)$. The parameters $\left(b_{l}, b_{e}, b_{s d c g}, b_{s i c g}, b_{p k}, b_{k}\right.$, $b_{s k}$ ) are obtained in the first stage of the estimation from (3) and $E\left[\omega_{i t} \mid \omega_{i t-1}\right]$ is estimated by regressing $\hat{\omega}_{i t}$ on fourth order polynomials in $\hat{\omega}_{i t-1} . \hat{\omega}_{i t}$ and $\hat{\omega}_{i t-1}$ are respectively obtained from (7) and (8) using the estimates obtained from the first stage and candidate values for $\left(b_{c}^{*}, b_{m}^{*}\right)$. The candidate values are the OLS estimates of (1).

$$
\begin{gathered}
\omega_{i t} \hat{+} \eta_{i t}=q_{i t}-\hat{b}_{l} l_{i t}-\hat{b}_{e} e_{i t}-\hat{b}_{s d c g} s d c g_{i t}-\hat{b}_{s i c g} \operatorname{sicg} g_{i t}-\hat{b}_{p k} p k_{i t}- \\
\hat{b}_{k} k_{i t}-\hat{b}_{s k} s k_{i t}-b_{c}^{*} c_{i t}-b_{m}^{*} m_{i t} \\
\hat{\omega}_{i t-1}=\hat{\phi}_{t-1}(.)-b_{c}^{*} c_{i t-1}-b_{m}^{*} m_{i t-1}
\end{gathered}
$$

We also use the following six additional moment restrictions to test the unbiasedness of the estimated coefficients of the choice variables of the firm, namely $c, l, m, e, k$ and $p k$.

$$
\begin{aligned}
& E\left[\xi_{i t} l_{i t-1}\right]=0, E\left[\xi_{i t} c_{i t-1}\right]=0, E\left[\xi_{i t} m_{i t-2}\right]=0, E\left[\xi_{i t} e_{i t-1}\right]=0, \\
& E\left[\xi_{i t} p k_{i t-1}\right]=0, E\left[\xi_{i t} k_{i t-1}\right]=0
\end{aligned}
$$

These over-identifying moment restrictions are valid under the null-hypothesis that the coefficient estimates are unbiased ${ }^{33}$. Thus, we have total eight population moment conditions given by the vector of expectations:

33 As suggested in Levinsohn and Petrin (2003), we also verified the empirical validity of the assumption that firms' rawmaterial demand varies monotonically with its productivity, given its capital stock, using graphical method and found that the assumption was valid in all cases. These graphs are reported in the appendix. 


$$
E\left[\left(\xi_{i t}+\eta_{i t}\right) Z_{i t}\right]
$$

Where $Z_{i t}$ is the vector given by

$$
Z_{i t}=\left\{c_{i t}, m_{i t-1}, c_{i t-1}, m_{i t-2}, l_{i t-1}, e_{i t-1}, p k_{i t-1}, k_{i t-1}\right\}
$$

Finally, estimates of $\left(b_{c}, b_{m}\right)$ are obtained by minimising the following GMM criterion function

$$
Q\left(b^{*}\right)=\min b^{*} \sum_{h=1}^{8}\left(\sum_{i} \sum_{t}^{T}\left(\xi_{i, t} \hat{+} \eta_{i, t}\left(b^{*}\right)\right) Z_{i, h, t}\right)^{2}
$$

where $i$ indexes firms, $h$ indexes eight instruments, and $T$ is the last period firm $i$ is observed.

Since the estimation involves several steps and accounting for the variances and covariances of estimates at each stage is a quite a difficult task, estimates have been bootstrapped to draw inference ${ }^{34}$. We use block-bootstrapping method, which treats time series observations on each firm as an independent and identical draw from the population of firms. The size of the bootstrap sample is the number of firms in the original sample. The number replications is five hundred. Since the estimation includes over-identifying moment restrictions, we use recentred moments in the bootstrap estimation to make sure that bootstrap samples implement moment conditions that are valid in the original data set from which it samples (see Horowitz 2001).

\section{Results}

The production function estimates are reported in Table 2. The row $\mathrm{P}(\mathrm{Q})$ reports the $\mathrm{P}$-value of the over-identification test under the

34 Bootstrap provides asymptotic refinements for asymptotically pivotal statistics like the ones in our case. In addition, the difference between the nominal and true coverage probabilities of the confidence interval can be reduced using critical values obtained from the bootstrap distribution (Horowitz 2001). 
Table 2. Production Function Estimates

\begin{tabular}{|c|c|c|c|}
\hline & All Industries & $\begin{array}{l}\text { Technology } \\
\text { Intensive } \\
\text { Industries }\end{array}$ & $\begin{array}{c}\text { Low Technology } \\
\text { Intensive } \\
\text { Industries }\end{array}$ \\
\hline 1 & $\begin{array}{c}0.1869 * \\
(0.008)\end{array}$ & $\begin{array}{c}0.2147 * \\
(0.013)\end{array}$ & $\begin{array}{c}0.1648 * \\
(0.009)\end{array}$ \\
\hline $\mathrm{e}$ & $\begin{array}{c}0.0697 * \\
(0.006)\end{array}$ & $\begin{array}{c}0.0467 * \\
(0.009)\end{array}$ & $\begin{array}{c}0.0909 * \\
(0.008)\end{array}$ \\
\hline $\operatorname{sdcg}$ & $\begin{array}{c}0.0902 * \\
(0.028)\end{array}$ & $\begin{array}{l}0.0680 \\
(0.054)\end{array}$ & $\begin{array}{c}0.1252 * \\
(0.031)\end{array}$ \\
\hline sicg & $\begin{array}{c}0.2040^{*} \\
(0.047)\end{array}$ & $\begin{array}{c}0.3821^{*} \\
(0.082)\end{array}$ & $\begin{array}{c}0.1378^{*} \\
(0.055)\end{array}$ \\
\hline pk & $\begin{array}{c}0.0019 * \\
(0.001)\end{array}$ & $\begin{array}{l}0.0008 \\
(0.001)\end{array}$ & $\begin{array}{l}0.0019 \\
(0.001)\end{array}$ \\
\hline $\mathrm{k}$ & $\begin{array}{c}0.0026 * \\
(0.001)\end{array}$ & $\begin{array}{c}0.0032 * \\
(0.001)\end{array}$ & $\begin{array}{l}0.0005 \\
0.001)\end{array}$ \\
\hline sk & $\begin{array}{c}0.0421 * \\
(0.006)\end{array}$ & $\begin{array}{c}0.0740 * \\
(0.023)\end{array}$ & $\begin{array}{c}0.0461 * \\
(0.013)\end{array}$ \\
\hline $\mathrm{c}$ & $\begin{array}{c}0.1648 * \\
(0.012)\end{array}$ & $\begin{array}{c}0.1409 * \\
(0.017)\end{array}$ & $\begin{array}{c}0.1755^{*} \\
(0.014)\end{array}$ \\
\hline $\mathrm{m}$ & $\begin{array}{c}0.6043^{*} \\
(0.011)\end{array}$ & $\begin{array}{c}0.6231 * \\
(0.018)\end{array}$ & $\begin{array}{c}0.5787 * \\
(0.014)\end{array}$ \\
\hline$P(Q)$ & 0.274 & 0.798 & 0.156 \\
\hline
\end{tabular}

Notes

(1) Bootstrap standard errors of estimates are given in parentheses. Number of replications is 500 .

(2) $\quad \mathrm{P}(\mathrm{Q})$ is the $\mathrm{P}$ value of over-identification test.

(3) * indicates significant at 5 per cent level implied by the bias corrected bootstrap confidence interval. 
null hypothesis that over-identification restrictions are valid. The null hypothesis is valid if the proxy is conditioning out all the variation in inputs that are correlated with the unobserved productivity ${ }^{35}$. The Table shows that in all cases the null is accepted at a reasonable level of statistical significance ${ }^{36}$.

The estimates for all industries show that rent spillovers through the purchase of machinery from both domestic and foreign sources are significant and the productivity effect of imported machinery share is higher than that purchased from domestic sources. More specifically, a one per cent increase in the share of machinery purchased from domestic sources increases output by 0.09 per cent and the corresponding figure for imported machinery is 0.20 per cent, more than twice the elasticity of domestic machinery share. The difference between the two is statistically significant. Sectoral results also show that imported machinery has grater contribution to output. In technology intensive industries, only imported machinery share is significant. Whereas, in low technology industries, elasticities of imported machinery share and that of domestic machinery share are not significantly different. This result may be due to the Indian machinery producing sector's differential capability in machine production. It may be able to produce machines, required by the low technology industries, of same quality as imported ones. But when it comes to the machinery required by the technology

35 In the presence of endogeneity of inputs, OLS and Fixed Effect (FE) estimates usually underestimate the coefficient of more fixed input and overestimate that of more flexible input (see Levinsohn and Petrin 2003). Our comparison of semi-parametric (SP) estimates with that of OLS and FE shows that in all industries OLS and FE estimates of capital are less than that of SP respectively by 24 and 60 per cent. Similarly OLS and FE estimates of energy coefficients are larger than that of SP respectively by 6 and 77 per cent. Our simulation results suggest that this underestimation of capital coefficient and overestimation energy coefficient by OLS and FE are not random, but systematic. These results are reported in the appendix.

36 We also estimated the model by including moment restrictions with respect to lagged values of $S K$, sicg and $s d c g$ along with other six moment restrictions. It also validated the over-identifying restrictions. 
intensive industries, it may not have the technological capability to produce machines of quality equal to that of imported ones, because of their greater technical sophistication.

The contribution of trade related knowledge spillover (sk) to output is positive and statistically significant in all cases. The estimates are based on the spillover knowledge stock constructed using one year lag in the effect of foreign R\&D on domestic productivity. Estimates based on two and three years lag also gave similar results. The elasticity of knowledge spillovers is higher in technology intensive industries. This may be reflecting the greater opportunities of this sector to learn from the technology leader countries.

Disembodied technology import stock (pk) is significant and positive in all industries. In the two sub-sectors, though it is positive in sign, is not significant. $R \& D$ is showing a significant positive contribution to output in all industries and in technology intensive industries. Earlier studies examining this issue using firm level data of 1970s and 1980s period, namely Ferrantino (1992), Raut (1995), Basant and Fikkert (1996) and Hasan (2002), found no significant effect of firm's R\&D on productivity ${ }^{37}$. The present study gives evidence of a positive contribution of R\&D to output in the 1990s. One possible reason for this can be that in the liberalised policy regime firms may be investing in more serious $\mathrm{R} \& \mathrm{D}$ to improve productivity and competitiveness.

One of our objectives is to examine the relationship between different technology variables with respect to their effect on productivity. This is analysed by estimating production function containing interaction of technology variables. A significant positive interaction term between two variables, say $k$ and $p k$, indicates a complementary relationship between the two in the sense that an increase in one enhances the marginal

In Basant and Fikkert (1996), R\&D has a significant positive effect only in estimates without time dummies. Raut (1995) found that intra-industry R\&D spillovers have a significant effect on productivity. 
product of other. On the other hand, if there exists a substitution relationship between the two, the interaction term would be insignificant or even negative if diminishing returns are operating in the technological investment. One problem in estimating the production function containing all the ten interaction variables is the severe multicollinearity among them, making all the interaction estimates insignificant. To overcome this, we group the interaction variables into two sets in such a way that one set contains only two interactions of a variable and estimating the production function using only one set at a time. The results are presented in Table 3.

The Table shows that interaction between the share of imported machinery and that of domestically produced machinery is statistically not significant. It can, therefore, be concluded that there is no evidence of a complementary relationship between the two. This evidence contradicts with the assumption made in some endogenous growth models that domestic and imported inputs are complements in production $^{38}$ (Romer 1994 and Lee 1995).

$\mathrm{R} \& \mathrm{D}$ and trade related knowledge spillovers are showing a complementary relationship in all industries and low technology industries. It is suggesting that in-house $R \& D$ is facilitating the absorption of knowledge spillovers. Similarly, the interaction between share of imported machinery and trade related knowledge spillovers is significant and positive in all industries and in low technology industries. This may be indicating that imported machinery is helping firms to absorb and utilise foreign knowledge spillovers, implying that the benefits of imported machinery go beyond its direct contribution.

38 Hasan (2002) using firm level data for the period 1975-76 to 1986-87 found a complementary relationship between imported machinery and domestically produced machinery. He argues that one can expect this result given the India government's policy of allowing firms to import capital goods only if it could be shown that a domestic substitute did not exist. The liberalised trade policy regime may have changed relation between imported machinery and domestically produced machinery. 


\begin{tabular}{|c|c|c|c|c|c|c|}
\hline & \multicolumn{2}{|c|}{ All Industries } & \multicolumn{2}{|c|}{$\begin{array}{c}\text { Technology intensive } \\
\text { Industries }\end{array}$} & \multicolumn{2}{|c|}{ Low Technology Industries } \\
\hline Variables & Group 1 & Group 2 & Group 1 & Group 2 & Group 1 & Group 2 \\
\hline 1 & $\begin{array}{l}0.1863^{*} \\
(0.008)\end{array}$ & $\begin{array}{l}0.1863^{*} \\
(0.008)\end{array}$ & $\begin{array}{c}0.2195^{*} \\
(0.013)\end{array}$ & $\begin{array}{r}0.2175^{*} \\
(0.013)\end{array}$ & $\begin{array}{r}0.1637 * \\
(0.009)\end{array}$ & $\begin{array}{l}0.1646^{*} \\
(0.009)\end{array}$ \\
\hline $\mathrm{e}$ & $\begin{array}{l}0.0695^{*} \\
(0.006)\end{array}$ & $\begin{array}{l}0.0698^{*} \\
(0.006)\end{array}$ & $\begin{array}{c}0.0469 * \\
(0.009)\end{array}$ & $\begin{array}{r}0.0469 * \\
(0.009)\end{array}$ & $\begin{array}{c}0.0911^{*} \\
(0.008)\end{array}$ & $\begin{array}{c}0.0915^{*} \\
(0.008)\end{array}$ \\
\hline $\operatorname{sdcg}$ & $\begin{array}{l}0.1212^{*} \\
(0.035)\end{array}$ & $\begin{array}{l}0.3281 \\
(0.217)\end{array}$ & $\begin{array}{c}0.1517^{*} \\
(0.074)\end{array}$ & $\begin{array}{l}0.0176 \\
(1.191)\end{array}$ & $\begin{array}{c}0.1061 * \\
(0.038)\end{array}$ & $\begin{array}{r}-0.2424 \\
(0.328)\end{array}$ \\
\hline sicg & $\begin{array}{l}-0.4929 \\
(0.257)\end{array}$ & $\begin{array}{l}0.2393^{*} \\
(0.056)\end{array}$ & $\begin{array}{l}0.4992 \\
(1.399)\end{array}$ & $\begin{array}{r}0.4423 * \\
(0.123)\end{array}$ & $\begin{array}{r}-1.7163 \\
(0.758)\end{array}$ & $\begin{array}{c}0.1889^{*} \\
(0.061)\end{array}$ \\
\hline $\mathrm{pk}$ & $\begin{array}{l}0.0039^{*} \\
(0.001)\end{array}$ & $\begin{array}{l}0.0011^{*} \\
(0.005)\end{array}$ & $\begin{array}{l}0.0030 \\
(0.002)\end{array}$ & $\begin{array}{l}0.0078 \\
(0.023)\end{array}$ & $\begin{array}{l}0.0023 \\
(0.002)\end{array}$ & $\begin{array}{r}-0.0082 \\
(0.010)\end{array}$ \\
\hline $\mathrm{k}$ & $\begin{array}{l}-0.0121 \\
(0.005)\end{array}$ & $\begin{array}{l}0.0034^{*} \\
(0.001)\end{array}$ & $\begin{array}{l}-0.0163 \\
(0.018)\end{array}$ & $\begin{array}{l}0.0050^{*} \\
(0.002)\end{array}$ & $\begin{array}{c}-0.0324^{*} \\
(0.013)\end{array}$ & $\begin{array}{r}-0.0011 \\
(0.002)\end{array}$ \\
\hline
\end{tabular}




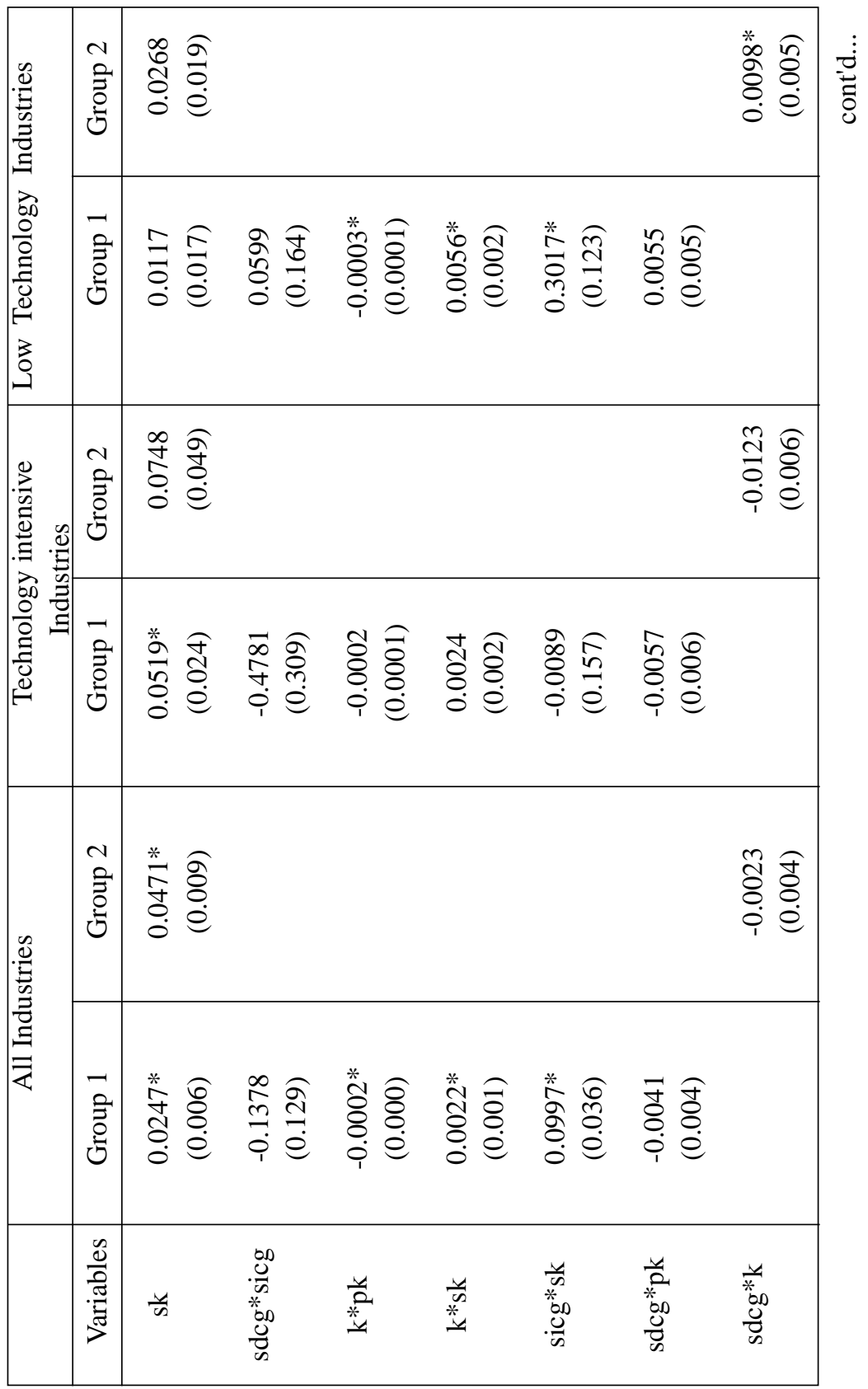




\begin{tabular}{|c|c|c|c|c|c|c|}
\hline \multirow{2}{*}{} & \multicolumn{2}{|c|}{ All Industries } & \multicolumn{2}{c|}{$\begin{array}{c}\text { Technology intensive } \\
\text { Industries }\end{array}$} & \multicolumn{2}{c|}{ Low Technology Industries } \\
\hline Variables & Group 1 & Group 2 & Group 1 & Group 2 & Group 1 & Group 2 \\
\hline \multirow{2}{*}{ sdcg*sk } & & -0.0316 & & 0.0139 & & 0.0568 \\
& & $(0.031)$ & & $(0.139)$ & & $(0.054)$ \\
sicg*pk & & -0.0034 & & -0.0065 & & -0.0081 \\
& & $(0.007)$ & & $(0.012)$ & & $(0.009)$ \\
sicg*k & & -0.0049 & & -0.0013 & & -0.0062 \\
& & $(0.007)$ & & $(0.011)$ & & $(0.009)$ \\
pk*sk & & 0.0002 & & -0.0008 & & 0.0018 \\
& & $(0.001)$ & & $(0.003)$ & & $(0.002)$ \\
c & $0.1634^{*}$ & $0.1636^{*}$ & $0.1409^{*}$ & $0.1418^{*}$ & $0.1771^{*}$ & $0.1761^{*}$ \\
& $(0.011)$ & $(0.012)$ & $(0.016)$ & $(0.018)$ & $(0.014)$ & $(0.014)$ \\
$\mathrm{m}$ & $0.6058^{*}$ & $0.6055^{*}$ & $0.6231^{*}$ & $0.6222^{*}$ & $0.5769^{*}$ & $0.5781^{*}$ \\
$\mathrm{P}(\mathrm{Q})$ & $(0.011)$ & $(0.011)$ & $(0.017)$ & $(0.018)$ & $(0.015)$ & $(0.015)$ \\
& 0.208 & 0.318 & 0.834 & 0.818 & 0.044 & 0.216 \\
\hline
\end{tabular}

Notes: (1) Bootstrap standard errors of estimates are given in parentheses; number of replications is 500.

(2) $\mathrm{P}(\mathrm{Q})$ is the $\mathrm{P}$ value of over identification test and * indicates significant at 5 per cent level implied by the bias corrected bootstrap confidence interval 
Another significant result is on the relationship between R\&D and disembodied technology import. The interaction between the two is significant and negative in all industries and low technology industries. It is suggesting a substitution relationship between the two. The relationship between $R \& D$ and technology import is one of the highly discussed issues in the technology literature in Indian context. One strand of the literature has the view that technology import would encourage investment in R\&D in order to adapt and assimilate the imported technology. Other strand argues that technology import would act as a substitute for in-house R\&D and discourages it. Hasan (2002) and Basant and Fikkert (1996) show that there is no evidence for a complementary or substitution relationship between the two. The results of the present study show that the interaction between the two is negative in all cases and significant in the case of all industries and in low technology sector. This is suggesting the absence of complementary relation between the two.

\section{Summary and Conclusion}

This paper has examined the effect of trade facilitated $R \& D$ spillovers on manufacturing productivity in the context of a developing country. Conceptually as well as empirically, trade related R\&D spillovers are distinguished into two types, namely rent spillovers and knowledge spillovers. The first one takes place through the import of capital goods embodying better technology and the second one though trade facilitated interaction of domestic producers with products, markets and producers of technology leader countries. The study also examined the intersectoral variation in the productivity effect of spillovers and the importance of firms' investment in R\&D, imported technology and plant and machinery in absorbing spillovers. The study is based on firm level panel data and an improved estimation framework.

The empirical results show that rent spillovers through imported machinery are higher than that through machinery purchased from domestic sources in technology intensive industries. Another important 
result is that trade facilitated knowledge spillovers have significant effect on productivity and in this case also technology intensive industries are gaining more than low technology industries. The study, thus, provides evidence for the existence of intersectoral variation in the productivity effect of trade related R\&D spillovers. The study also shows that imported machinery and investment in $R \& D$ are enhancing the effect on productivity. This suggests that the benefit of imported machinery go beyond its direct contribution and also highlights the importance of developing in-house R\&D capability to effectively absorb knowledge from technology leaders though trade interaction.

M. Parameswaran is Research Associate at the Centre for Development Studies, Thiruvananthapuram. His research interests include International Trade, Economic Growth, Industrial Economics and Applied Econometrics. email:parameswaran@cds.ac.in 


\section{Appendix}

\section{A1. Checking for the monotonicity assumption.}

This specification test check for the empirical validity of the assumption that firm's raw material demand is monotonically increasing in its productivity, given the level of capital. It is implemented by simply graphing the smoothed $\omega_{i t}=\omega_{t}\left(c_{i t}, m_{i t}\right)$ against raw materials and capital stock. For monotonicity condition to hold, this function should be increasing in materials, given the level of capital. Since this function is allowed to be different in three sub-periods of the sample, there are nine such functions to graph. Therefore to save space, we are reporting here only the three graphs related to all industries. These graphs, reported in Figure A1, Figure A2 and Figure A3, show that material consumption is increasing in productivity, given the level of capital stock.

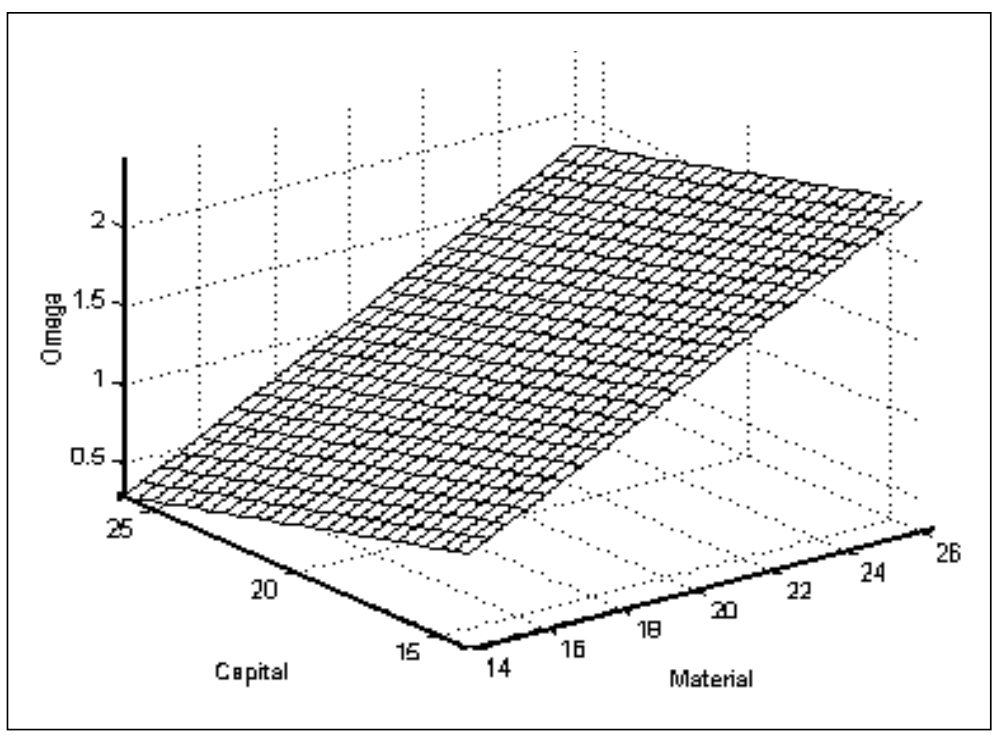

Figure A1 Productivity (Omega) as a Function of Capital and MaterialsPeriod 1 


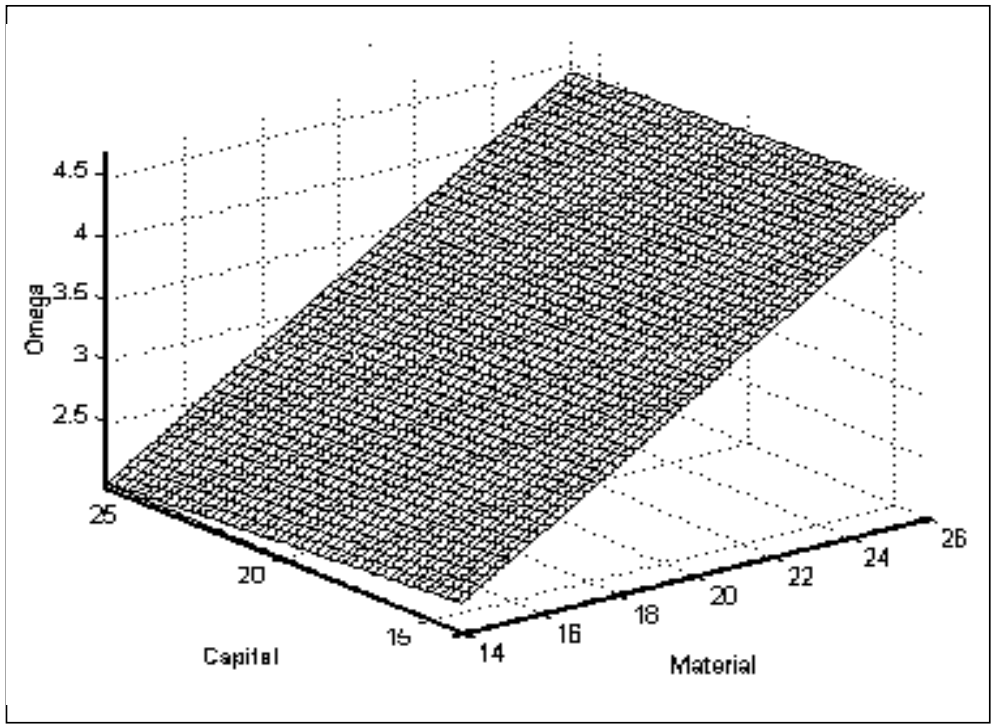

Figure A.2 Productivity (Omega) as a Function of Capital and Materials-Period 2

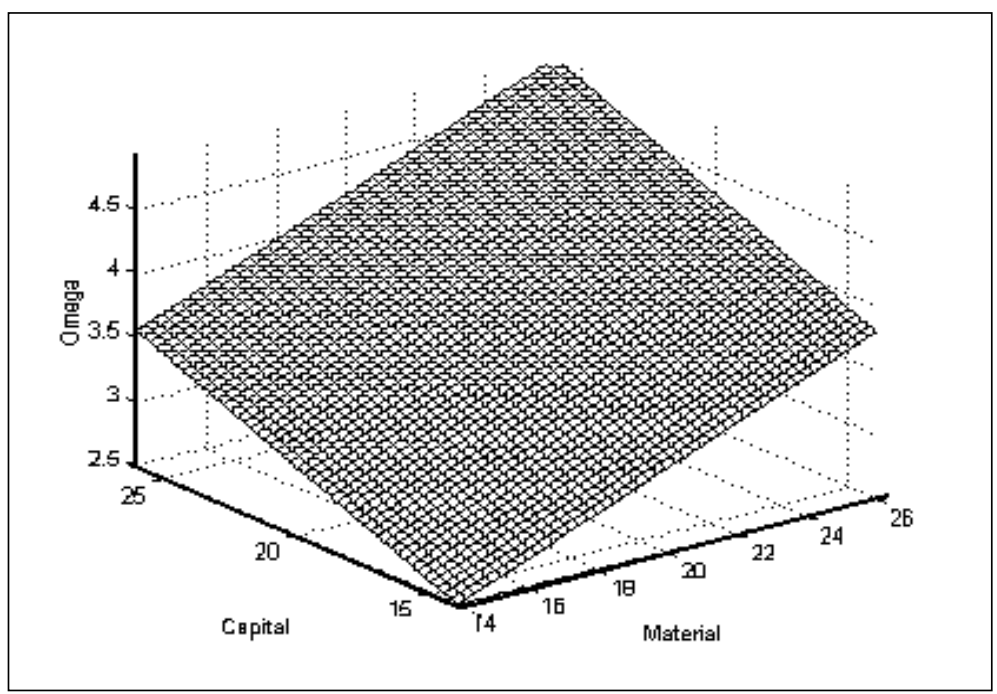

Figure A.3 Productivity (Omega) as a Function of Capital and Materials- Period 3 
A2. Difference of OLS and Fixed Effect estimates from Semiparametric (SP) estimates.

Table A2.1 Difference of OLS and FE Estimates from SP Estimates

\begin{tabular}{|c|c|c|c|c|}
\hline Input & & $\begin{array}{c}\text { All } \\
\text { Industries }\end{array}$ & $\begin{array}{l}\text { Technology } \\
\text { Intensive } \\
\text { Industries }\end{array}$ & $\begin{array}{c}\text { Low } \\
\text { Technology } \\
\text { Sector }\end{array}$ \\
\hline \multirow[t]{2}{*}{ Capital } & $\beta_{\mathrm{OLS}}-\beta_{\mathrm{SP}} \%>0$ & $\begin{array}{c}-0.0399 \\
0.0\end{array}$ & $\begin{array}{c}-0.0435 \\
0.0\end{array}$ & $\begin{array}{c}-0.0226 \\
0.0\end{array}$ \\
\hline & $\beta_{\mathrm{FE}}-\beta_{\mathrm{SP}} \%>0$ & $\begin{array}{c}-0.0994 \\
0.0\end{array}$ & $\begin{array}{c}-0.0594 \\
0.0\end{array}$ & $\begin{array}{c}-0.1161 \\
0.0\end{array}$ \\
\hline \multirow[t]{2}{*}{ Labour } & $\beta_{\mathrm{OLS}}-\beta_{\mathrm{SP}} \%>0$ & $\begin{array}{c}-0.0083 \\
1.0\end{array}$ & $\begin{array}{c}0.0013 \\
66.0\end{array}$ & $\begin{array}{c}-0.0224 \\
0.0\end{array}$ \\
\hline & $\beta_{\mathrm{FE}}-\beta_{\mathrm{SP}} \%>0$ & $\begin{array}{c}-0.0018 \\
49.2\end{array}$ & $\begin{array}{c}-0.0911 \\
0.0\end{array}$ & $\begin{array}{c}0.0725 \\
99.8\end{array}$ \\
\hline \multirow[t]{2}{*}{ Material } & $\beta_{\mathrm{OLS}}-\beta_{\mathrm{SP}} \%>0$ & $\begin{array}{c}0.0025 \\
66.4\end{array}$ & $\begin{array}{c}0.0038 \\
59.6\end{array}$ & $\begin{array}{c}0.0088 \\
90.4\end{array}$ \\
\hline & $\beta_{\mathrm{FE}}-\beta_{\mathrm{SP}} \%>0$ & $\begin{array}{c}0.008 \\
71.4\end{array}$ & $\begin{array}{c}0.0327 \\
93.6\end{array}$ & $\begin{array}{c}-0.0071 \\
33.8\end{array}$ \\
\hline \multirow[t]{2}{*}{ Energy } & $\beta_{\mathrm{OLS}}-\beta_{\mathrm{SP}} \%>0$ & $\begin{array}{c}0.0039 \\
92.8\end{array}$ & $\begin{array}{c}-0.0010 \\
45.0\end{array}$ & $\begin{array}{c}0.0099 \\
97.2\end{array}$ \\
\hline & $\beta_{\mathrm{FE}}-\beta_{\mathrm{SP}} \%>0$ & $\begin{array}{c}0.0539 \\
100.0\end{array}$ & $\begin{array}{c}0.0755 \\
100.0\end{array}$ & $\begin{array}{c}0.0348 \\
99.4\end{array}$ \\
\hline
\end{tabular}

Note: Where $\beta_{\mathrm{OLS}}-\beta_{\mathrm{SP}}$ and $\beta_{\mathrm{FE}}-\beta_{\mathrm{SP}}$ respectively denote the difference of OLS and FE estimate form SP estimates. $\%>0$ indicates the percentage of differences greater than zero in the 500 bootstrap estimates 
The Table A2.1 reports the difference of OLS and Fixed Effect estimates from those of SP and the pattern of distribution of these differences in 500 bootstrap estimates. The distribution is created by drawing 500 bootstrap samples and estimating the production function from each sample using OLS, FE and SP methods. The upper part of each row gives the difference of OLS or FE estimates from SP and the lower part shows percentage of differences having value greater than zero. 


\section{References}

Basant, Rakesh. and Brian Fikkert. (1996) "The Effects of R\&D, Foreign Technology Purchase, and Domestic and International Spillovers on Productivity in Indian Firms," Review of Economics and Statistics, Vol. 78, pp. 187-199.

Ben-Davi, Dan. And Michaeal Loewy (1998) "Free trade, growth and convergence", Journal of Economic Growth, Vol. 3, pp.143-170.

Berndt, Ernst R. and Catherine J. Morrison. (1995) "High-tech Capital Formation and Economic Performance in US Manufacturing Industries: An Exploratory Analysis," Journal of Econometrics, Vol. 65, pp. 9-43.

Coe, David T. and Elhanan Helpman. (1995) "International R\&D Spillovers,” European Economic Review, Vol.39, pp.859-887.

Coe, David T.; Elhanan Helpman and Alexander W. Hoffmaister. (1997) "North- South R\&D Spillovers," The Economic Journal, Vol. 107, pp. 134-49.

Cohen, Wesley M. and Daniel A. Levinthal. (1989) "Innovation and Learning: The Two Faces of R\&D," The Economic Journal, Vol. 99, pp. 569-596.

Connolly, Michelle. (2003) "The Dual Nature of Trade: Measuring its Impact on Imitation and Growth," Journal of Development Economics, Vol. 72, pp.31-55.

Dennison, Edward F. (1967) Why Growth Rates Differ: Post-War Experience in Nine Western Countries, The Brookings Institution, Washington D.C.

Deolalikar, Anil B and Robert E. Evenson. (1989) “Technology Production and Technology Purchase in Indian Industry: An Econometric Analysis," Review of Economics and Statistics, Vol.71, Pp. 687-692. 
Eaton, Jonathan and Samuel Kortum. (2001) "Trade in Capital Goods," European Economic Review, Vol.45, pp.1195-1235.

Egan, Mary Lou and Ashok Mody. (1992) "Buyer-Seller Links in Export Development," World Development, Vol. 20, pp.321-334.

Ferrantino, Michael J. (1992) “Technology Expenditures, Factor Intensity and Efficiency in Indian Manufacturing," Review of Economics and Statistics, Vol. 74, pp. 689-700.

Funk, Mark. (2001) "Trade and International R\&D Spillovers among OECD Countries," Southern Economic Journal, Vol. 67, pp. 725-736.

Griliches, Zvi and Jacques Mairesse. (1998) "Production Functions: The Search for Identification," In: Zvi Griliches (ed.) Practicing Econometrics, Essays in Methods and Applications, Edward Elgar, Cheltenham.

Griliches, Zvi. (1979) "Issues in Assessing the Contribution of Research and Development to Productivity Growth," Bell Journal of Economics, Vol. 10, pp. 92-116.

Griliches, Zvi. (1992) “The Search for R\&D Spillovers," Scandinavian Journal of Economics, Vol. 94, pp. 29-47.

Grossman, Gene M. and Elhanan Helpman. (1991) Innovation and Growth in the Global Economy, The MIT Press, Cambridge M.A.

Hasan, Rana. (2002) "The Impact of Imported and Domestic Technologies on the Productivity of Firms: Panel Data Evidence From Indian Manufacturing Firms," Journal of Development Economics, Vol. 69, pp. 23-49.

Heston, Alan. (1994) "A Brief Review of some Problems in Using National Accounts Data in Level of Output Comparisons and Growth Studies," Journal of Development Economics, Vol. 44, pp. 29-52. 
Horowitz, Joel L. (2001) “The Bootstrap,” In: James J. Heckman and Edward Leamer (ed.) Handbook of Econometrics Vol. 5, Elsevier, Amsterdam, pp. 3159-3228.

Keller, Wolfgang. (2000) "Do Trade Patterns and Technology Flows Affect Productivity Growth?," The World Bank Economic Review, Vol. 14, pp. 17-47.

Keller, Wolfgang. (2004) "International Technology Diffusion," Journal of Economic Literature, Vol.42, pp.752-782.

Kruger, Anne O. (1998) "Why Trade Liberalisation is Good for Growth," The Economic Journal, Vol.108, pp.1513-1522.

Lee, Jong-Wha. (1995) "Capital Goods Imports and Long-run Growth," Journal of Development Economics, Vol. 48, pp. 91-110.

Levinsohn, James and Amil Petrin. (2003) "Estimating Production Functions Using Inputs to Control for Unobservables," Review of Economic Studies, Vol.70, pp. 317-341.

Nicita, Alessandro and Marcelo Olarreaga (2001) Trade and Production, 1976-1999, World Bank Working Paper, (available at: www.worldbank.org/research/trade)

OECD (2000) Research and Development Expenditure in Industry 19771998, Organisation for Economic Co-operation and Development, Paris.

Olley, G. Steven and Ariel Pakes. (1996) "The Dynamics of Productivity in the Telecommunication Equipment Industry," Econometrica, Vol. 64 (6), pp. 1263-97.

Parameswaran, M. (2002) Economic Reforms and Technical Efficiency: Firm Level Evidence from Selected Industries in India, Working Paper No. 339, Centre for Development Studies, Kerala, India (Available from $w w w . c d s . e d u$ ).

Prescott, Edward. (1998) "Needed a theory of Total Factor Productivity", International Economic Review, Vol. 39, pp. 525-51. 
Raut, Lakshmi. (1988) "R\&D Behaviour of Indian Firms: A Stochastic Control Model," Indian Economic Review, Vol. 23, pp. 207-229.

Romer, Paul M. (1994) "New Goods, Old Theory, and the Welfare Cost of Trade Restrictions," Journal of Development Economics, Vol. 43, pp. 5-38.

Schmitz, H. and P. Knorringa. (2000) "Learning from Global Buyers," The Journal of Development Studies, Vol. 37(2) pp. 177-205.

Srivastava, Vivek. (1996) Liberalisation, Productivity and Competition: A Panel Study of Indian Manufacturing, Oxford University Press, New Delhi.

Xu, Bin and Jianmao Wang. (1999) "Capital Goods Trade and R\&D Spillovers in the OECD," Canadian Journal of Economics, Vol.32, pp. 1258-1274. 


\title{
CENTRE FOR DEVELOPMENT STUDIES
}

\section{LIST OF WORKING PAPERS}

\author{
[New Series]
}

The Working Paper Series was initiated in 1971. A new series was started in 1996 from WP. 270 onwards. Working papers beginning from 279 can be downloaded from the Centre's website (www.cds.edu)

W.P. 384 K. C. ZACHARIAH, S. IRUDAYA RAJAN Economic and Social Dynamics of Migration in Kerala, 1999-2004 Analysis of Panel Data. May 2007.

W.P. 383 SAIKAT SINHA ROY Demand and Supply Factors in the Determination or India's Disaggregated Manufactured Exports : A Simultaneous Error-Correction Approach. May 2007

W.P. 382 SUNIL MANI The Sectoral System of Innovation of Indian pharmaceutical industry. September 2006

W.P. 381 K. J. JOSEPH, GOVINDAN PARAYIL Trade Liberalization and Digital Divide: An Analysis of the Information Technology Agreement of WTO. July 2006.

W.P. 380 RUDRA NARAYAN MISHRA Dynamics of Caste-based Deprivation in Child Under-nutrition in India. July 2006.

W.P. 379 P.L.BEENA, Limits to Universal Trade Liberalisation: The Contemporary Scenario for Textiles \& Clothing Sector in South Asia. March 2006.

W.P. 378 K.N. NAIR, VINEETHA MENON, Lease Farming in Kerala: Findings from Micro Level Studies. November 2005.

W.P. 377 NANDANA BARUAH, Anti Dumping Duty as a Measure of Contingent Protection: An Analysis of Indian Experience. October 2005.

W.P. 376 P. MOHANAN PILLAI, N. SHANTA Long Term Trends in the Growth and Structure of the Net State Domestic Product in Kerala. October 2005.

W.P. 375 R. MOHAN, D. SHYJAN Taxing Powers and Developmental Role of the Indian States: A Study with reference to Kerala. August 2005.

W.P. 374 K. C. ZACHARIAH, S. IRUDAYA RAJAN. Unemployment in Kerala at the Turn of the Century: Insights from CDS Gulf Migration Studies. August 2005. 
W.P. 373 SUNIL MANI, The Dragon vs. The Elephant Comparative Analysis of Innovation Capability in the Telecommunications Equipment Industry in China and India. July 2005

W.P. 372 MOTKURI VENKATANARAYANA On The Non-Random Distribution of Educational Deprivation of Children in India. July 2005

W.P. 371 DIBYENDU S. MAITI Organisational Morphology of Rural Industries in Liberalised India: A Study of West Bengal. June 2005

W.P. 370 SUNIL MANI, Keeping Pace with Globalisation Innovation Capability in Korea's Telecommunications Equipment Industry. March 2005.

W.P. 369 V.R. PRABHAKARAN NAIR, Determinants of Fixed Investment: A Study of Indian Private Corporate Manufacturing Sector. March 2005.

W.P. 368 J. DEVIKA, Modernity with Democracy? : Gender and Governance in the People's Planning Campaign, Keralam. February 2005

W.P. 367 VINEETHA MENON, ANTONYTO PAUL, K N NAIR Dynamics of Irrigation Institutions: Case study of a Village Panchayat in Kerala. February 2005

W.P. 366 VIJAYAMOHANAN PILLAI N. Causality and Error Correction in Markov Chain: Inflation in India Revisited. December 2004.

W.P. 365 R. MOHAN. Central Finances in India - Alternative to Procrustean Fiscal Correction. November 2004.

W.P. 364 SUNIL MANI. Coping with Globalisation Public R\&D Projects in Telecommunications Technologies in Developing Countries. November 2004.

W.P.363 K C ZACHARIAH, S IRUDAYA RAJAN. Gulf Revisited Economic Consequences of Emigration From Kerala, Emigration and Unemployment. September 2004.

W.P.362 M. VENKATANARAYANA. Educational Deprivation of Children in Andhra Pradesh, Levels and Trends, Disparities and Associative Factors. August 2004.

W.P.361 K.P. KANNAN, VIJAYAMOHANAN PILLAI N. Development as a Right to Freedom: An Interpretation of the Kerala Model. August 2004. 
W.P. 360 VIJAYAMOHANAN PILLAI N. CES Function, Generalised Mean and Human Poverty Index: Exploring Some Links. July 2004.

W.P. 359 PRAVEENA KODOTH, Shifting the Ground of Fatherhood: Matriliny, Men and Marriage in Early Twentieth Century Malabar. May 2004.

W.P. 358 MRIDUL EAPEN. Women and Work Mobility: Some Disquieting Evidences from the Indian Data. May 2004.

W.P. 357 K. RAVI RAMAN. The Asian Development Bank Loan for Kerala (India): The Adverse Implications and Search for Alternatives, March 2004.

W.P. 356 VIJAYAMOHANAN PILLAI N. Liberalisation of Rural Poverty: The Indian Experience, March 2004.

W.P. 355 P.L.BEENA Towards Understanding the Merger-Wave in the Indian Corporate Sector: A Comparative Perspective, January 2004.

W.P. 354 K.P. KANNAN AND R. MOHAN India's Twelfth Finance Commission A View from Kerala, December 2003.

W.P. 353 K.N. HARILAL AND P.L. BEENA The WTO Agreement on Rules of Origin Implications for South Asia, December 2003.

W.P. 352 K. PUSHPANGADAN Drinking Water and Well-being In India: Data Envelopment Analysis, October 2003.

W.P. 351 INDRANI CHAKRABORTY Liberalization of Capital Inflows and the Real Exchange Rate in India : A VAR Analysis, September 2003.

W.P. 350 M.KABIR Beyond Philanthropy: The Rockefeller Foundation's Public Health Intervention in Thiruvithamkoor, 1929-1939, September 2003.

W.P. 349 JOHN KURIEN The Blessing of the Commons : Small-Scale Fisheries, Community Property Rights, and Coastal Natural Assets, August 2003.

W.P. 348 MRIDUL EAPEN, Rural Industrialisation in Kerala: ReExamining the Issue of Rural Growth Linkages, July 2003.

W.P. 347 RAKHE PB, Estimation of Tax Leakage and its Impact on Fiscal Health in Kerala, July 2003.

W.P. 346 VIJAYAMOHANAN PILLAI N, A contribution to Peak load pricing theory and Application. April 2003.

W.P. 345 V.K. RAMACHANDRAN, MADHURA SWAMINATHAN, VIKAS RAWAL Barriers to Expansion of Mass Literacy and 
Primary Schooling in West Bengal: Study Based on Primary Data from Selected Villages. April 2003.

W.P. 344 PRADEEP KUMAR PANDA Rights-Based Strategies in the Prevention of Domestic Violence, March 2003.

W.P. 343 K. PUSHPANGADAN Remittances, Consumption and Economic growth in Kerala: 1980-2000, March 2003.

W.P. 342 D NARAYANA Why is the Credit-deposit Ratio Low in Kerala? January 2003.

W.P. 341 MRIDUL EAPEN, PRAVEENA KODOTH Family Structure, Women's Education and Work: Re-examining the High Status of Women in Kerala. November 2002.

W.P. 340 J. DEVIKA, Domesticating Malayalees: Family Planning, the Nation and Home-Centered Anxieties in Mid-20 $0^{\text {th }}$ Century Keralam. October, 2002.

W.P. 339 M PARAMESWARAN, Economic Reforms and Technical Efficiency: Firm Level Evidence from Selected Industries in India. October, 2002.

W.P. 338 PRAVEENA KODOTH, Framing Custom, Directing Practices: Authority, Property and Matriliny under Colonial Law in Nineteenth Century Malabar, October 2002.

W.P. 337 K.NAVANEETHAM, Age Structural Transition and Economic Growth: Evidence From South and Southeast Asia, August 2002.

W.P. 336 PULAPRE BALAKRISHNAN, K. PUSHPANGADAN, M. SURESH BABU, Trade Liberalisation, Market Power and Scale Efficiency in Indian Industry, August 2002.

W.P. 335 J. DEVIKA, Family Planning as 'Liberation': The Ambiguities of 'Emancipation from Biology' in Keralam July 2002.

W.P. 334 E. ABDUL AZEEZ, Economic Reforms and Industrial Performance an Analysis of Capacity Utilisation in Indian Manufacturing, June 2002.

W.P. 333 K. PUSHPANGADAN Social Returns from Drinking Water, Sanitation and Hygiene Education: A Case Study of Two Coastal Villages in Kerala, May 2002.

W.P. 332 K. P. KANNAN, The Welfare Fund Model of Social Security for Informal Sector Workers: The Kerala Experience. April 2002.

W.P. 331 SURESH BABU, Economic Reforms and Entry Barriers in Indian Manufacturing. April 2002. 
W.P. 330 ACHIN CHAKRABORTY, The Rhetoric of Disagreement in Reform Debates April 2002.

W.P. 329 J. DEVIKA, Imagining Women's Social Space in Early Modern Keralam. April 2002.

W.P. 328 K. P. KANNAN, K. S. HARI, Kerala's Gulf Connection Emigration, Remittances and their Macroeconomic Impact 19722000. March 2002.

W.P. 327 K. RAVI RAMAN, Bondage in Freedom, Colonial Plantations in Southern India c. 1797-1947. March 2002.

W.P. 326 K.C.ZACHARIAH, B.A. PRAKASH, S. IRUDAYA RAJAN, Gulf Migration Study : Employment, Wages and Working Conditions of Kerala Emigrants in the United Arab Emirates. March 2002.

W.P. 325 N. VIJAYAMOHANAN PILLAI, Reliability and Rationing cost in a Power System. March 2002.

W.P. 324 K. P. KANNAN, N. VIJAYAMOHANAN PILLAI, The Aetiology of the Inefficiency Syndrome in the Indian Power Sector Main Issues and Conclusions of a Study. March 2002.

W.P. 323 V. K. RAMACHANDRAN, MADHURA SWAMINATHAN, VIKAS RAWAL, How have Hired Workers Fared? A Case Study of Women Workers from an Indian Village, 1977 to 1999. December 2001.

W.P. 322 K. C. ZACHARIAH, The Syrian Christians of Kerala: Demographic and Socioeconomic Transition in the Twentieth Century, November 2001.

W.P. 321 VEERAMANI C. Analysing Trade Flows and Industrial Structure of India: The Question of Data Harmonisation, November 2001.

W.P. 320 N. VIJAYAMOHANAN PILLAI, K. P. KANNAN, Time and Cost Over-runs of the Power Projects in Kerala, November 2001.

W.P. 319 K. C. ZACHARIAH, P. R. GOPINATHAN NAIR, S. IRUDAYARAJAN Return Emigrants in Kerala: Rehabilitation Problems and Development Potential. October 2001

W.P. 318 JOHN KURIEN, ANTONYTO PAUL Social Security Nets for Marine Fisheries-The growth and Changing Composition of Social Security Programmes in the Fisheries Sector of Kerala State, India. September 2001. 
W.P. 317 K. J. JOSEPH, K. N. HARILAL India's IT Export Boom: Challenges Ahead. July 2001.

W.P. 316 K. P. KANNAN, N. VIJAYAMOHANAN PILLAI The Political Economy of Public Utilities: A Study of the Indian Power Sector, June 2001.

W.P. 315 ACHIN CHAKRABORTY The Concept and Measurement of Group Inequality, May 2001.

W.P. 314 U.S.MISHRA, MALA RAMANATHAN Delivery Compli-cations and Determinants of Caesarean Section Rates in India - An Analysis of National Family Health Surveys, 1992-93, March 2001.

W.P. 313 VEERAMANI. C India's Intra-Industry Trade Under Economic Liberalization: Trends and Country Specific Factors, March 2001

W.P. 312 N. VIJAYAMOHANAN PILLAI Electricity Demand Analysis and Forecasting -The Tradition is Questioned, February 2001

W.P. 311 INDRANI CHAKRABORTY Economic Reforms, Capital Inflows and Macro Economic Impact in India, January 2001

W.P. 310 K. K. SUBRAHMANIAN. E. ABDUL AZEEZ, Industrial Growth In Kerala: Trends And Explanations November 2000

W.P. 309 V.SANTHAKUMAR, ACHIN CHAKRABORTY, Environmental Valuation and its Implications on the Costs and Benefits of a Hydroelectric Project in Kerala, India, November 2000.

W.P. 308 K. P. KANNAN, N . VIJAYAMOHANAN PILLAI, Plight of the Power Sector in India : SEBs and their Saga of Inefficiency November 2000.

W.P. 307 K. NAVANEETHAM, A. DHARMALINGAM, Utilization of Maternal Health Care Services in South India, October 2000.

W.P. 306 S. IRUDAYA RAJAN, Home Away From Home: A Survey of Oldage Homes and inmates in Kerala, August 2000.

W.P. 305 K. N. HARILAL, K.J. JOSEPH, Stagnation and Revival of Kerala Economy: An Open Economy Perspective, August 2000.

W.P. 304 K. P. KANNAN, Food Security in a Regional Perspective; A View from 'Food Deficit' Kerala, July 2000.

W.P. 303 K. C. ZACHARIAH, E. T. MATHEW, S. IRUDAYA RAJAN, Socio-Economic and Demographic Consequenes of Migration in Kerala, May 2000.

W.P. 302 K. PUSHPANGADAN, G. MURUGAN, Gender Bias in a Marginalised Community: A Study of Fisherfolk in Coastal Kerala, May 2000.

W.P. 301 P. L. BEENA An Analysis of Mergers in the Private Corporate Sector in India, March, 2000. 
W.P. 300 D. NARAYANA Banking Sector Reforms and the Emerging Inequalities in Commercial Credit Deployment in India, March, 2000.

W.P. 299 JOHN KURIEN Factoring Social and Cultural Dimensions into Food and Livelihood Security Issues of Marine Fisheries; A Case Study of Kerala State, India, February, 2000.

W.P. 298 D. NARAYANA, K. K. HARI KURUP, Decentralisation of the Health Care Sector in Kerala : Some Issues, January, 2000.

W.P. 297 K.C. ZACHARIAH, E. T. MATHEW, S. IRUDAYA RAJAN Impact of Migration on Kerala's Economy and Society, July, 1999.

W.P. 296 P.K. MICHAEL THARAKAN, K. NAVANEETHAM Population Projection and Policy Implications for Education:A Discussion with Reference to Kerala, July, 1999.

W.P. 295 N. SHANTA, J. DENNIS RAJA KUMAR Corporate Statistics: The Missing Numbers, May, 1999.

W.P. 294 K. P. KANNAN Poverty Alleviation as Advancing Basic Human Capabilities: Kerala's Achievements Compared, May, 1999.

W.P. 293 MRIDUL EAPEN Economic Diversification In Kerala : A Spatial Analysis, April, 1999.

W.P. 292 PRADEEP KUMAR PANDA Poverty and young Women's Employment: Linkages in Kerala, February, 1999.

W.P. 291 P. K. MICHAEL THARAKAN Coffee, Tea or Pepper? Factors Affecting Choice of Crops by Agro-Entrepreneurs in Nineteenth Century South-West India, November 1998

W.P. 290 CHRISTOPHE Z. GUILMOTO, S. IRUDAYA RAJAN Regional Heterogeneity and Fertility Behaviour in India, November 1998.

W.P. 289 JOHN KURIEN Small Scale Fisheries in the Context of Globalisation, October 1998.

W.P. 288 S. SUDHA, S. IRUDAYA RAJAN Intensifying Masculinity of Sex Ratios in India : New Evidence 1981-1991, May 1998.

W.P. 287 K. PUSHPANGADAN, G. MURUGAN Pricing with Changing Welfare Criterion: An Application of Ramsey-Wilson Model to Urban Water Supply, March 1998.

W.P. 286 ACHIN CHAKRABORTY The Irrelevance of Methodology and the Art of the Possible : Reading Sen and Hirschman, February 1998.

W.P. 285 V. SANTHAKUMAR Inefficiency and Institutional Issues in the Provision of Merit Goods, February 1998. 
W.P. 284 K. P. KANNAN Political Economy of Labour and Development in Kerala, January 1998.

W.P. 283 INDRANI CHAKRABORTY Living Standard and Economic Growth: A fresh Look at the Relationship Through the Non-Parametric Approach, October 1997.

W.P. 282 S. IRUDAYA RAJAN, K. C. ZACHARIAH Long Term Implications of Low Fertility in Kerala, October 1997.

W.P. 281 SUNIL MANI Government Intervention in Industrial $R \& D$, Some Lessons from the International Experience for India, August 1997.

W.P. 280 PRADEEP KUMAR PANDA Female Headship, Poverty and Child Welfare : A Study of Rural Orissa, India, August 1997.

W.P. 279 U.S. MISRA, MALA RAMANATHAN, S. IRUDAYA RAJAN Induced Abortion Potential Among Indian Women, August 1997.

W. P. 278 PRADEEP KUMAR PANDA The Effects of Safe Drinking Water and Sanitation on Diarrhoeal Diseases Among Children in Rural Orissa, May 1997.

W. P. 277 PRADEEP KUMAR PANDA Living Arrangements of the Elderly in Rural Orissa, May 1997.

W. P. 276 V. SANTHAKUMAR Institutional Lock-in in Natural Resource Management: The Case of Water Resources in Kerala, April 1997.

W.P. 275 G. OMKARNATH Capabilities and the process of Development March 1997.

W.P. 274 K. PUSHPANGADAN, G. MURUGAN User Financing \& Collective action: Relevance sustainable Rural water supply in India. March 1997.

W.P. 273 ROBERT E. EVENSON, K.J. JOSEPH Foreign Technology Licensing in Indian Industry: An econometric analysis of the choice of partners, terms of contract and the effect on licensees' performance March 1997.

W.P. 272 SUNIL MANI Divestment and Public Sector Enterprise Reforms, Indian Experience Since 1991 February 1997.

W.P. 271 SRIJIT MISHRA Production and Grain Drain in two inland Regions of Orissa December 1996.

W.P. 270 ACHIN CHAKRABORTY On the Possibility of a Weighting System for Functionings December 1996. 


\section{Books Published by the CDS}

Biodiversity, Sustainable Development and Economic Analysis

J. Hans B. Opschoor

CDS, 2004, Rs. 100/\$11

Plight of the Power Sector in India: Inefficiency, Reform and Political Economy

K.P. Kannan and N. Vijayamohanan Pillai

CDS, 2002, Rs. 400/\$40

Kerala's Gulf Connection: CDS Studies on International Labour Migration from Kerala State in India

K.C. Zachariah, K. P. Kannan, S. Irudaya Rajan (eds)

CDS, 2002, pp 232, Hardcover, Rs. 250/\$25

Performance of Industrial Clusters: A Comparative Study of Pump Manufacturing Cluster in Coimbatore (Tamil Nadu) \& Rubber Footwear Cluster in Kottayam (Kerala)

P. Mohanan Pillai

CDS, 2001, pp 158, Paperback, Rs. 175/\$18

Poverty, Unemployment and Development Policy : A Case Study of Selected Issues With Reference to Kerala

United Nations, 2000 (reprint), pp 235

(available for sale in India only), Rs. 275

Land Relations and Agrarian Development in India:A Comparative Historical Study of Regional Variations

Sakti Padhi

CDS,1999. pp 335, Hardcover, Rs. 425/\$48

Agrarian Transition Under Colonialism: Study of A Semi Arid Region of Andhra, C.1860-1900

GN Rao

CDS,1999. pp 133, Paperback, Rs. 170/ \$19

Property Rights, Resource Management \& Governance: Crafting An Institutional Framework for Global Marine Fisheries John Kurien

CDS \& SIFFS, 1998. pp 56, Paperback, Rs. 50/ \$10 
Health, Inequality and Welfare Economics

Amartya Sen

CDS. 1996. pp 26, Paperback, Rs. 70/ \$ 10

Industrialisation in Kerala: Status of Current Research and Future Issues

P Mohanan Pillai \& N Shanta

CDS. 1997. pp 74, Paperback, Rs. 110/ \$ 12

CDS M.Phil Theses (1990/91-1993/94): A Review Vol.II

T T Sreekumar

CDS. 1996. pp 99, Paperback, Rs. 120/\$ 14

Trends In Agricultural Wages in Kerala 1960-1990

A A Baby

CDS. 1996. pp 83, Paperback, Rs. 105/ \$ 12

CDS M.Phil Theses (1975/76-1989/90): A Review Vol.1

G N Rao

CDS. 1996. pp 162, Paperback, Rs. 155/ \$ 18

Growth of Education in Andhra - A Long Run View

C Upendranath

CDS. 1994. pp 158, Paperback, Rs. 135/ \$ 15

Growth of Market Towns in Andhra: A Study of the Rayalseema Region C 1900-C.1945

Namerta

CDS. 1994. pp 186, Paperback, Rs.125/ \$ 14

Floods and Flood Control Policies: an Analysis With Reference to the Mahanadi Delta in Orissa

Sadhana Satapathy

CDS. 1993 pp 98, Paperback, Rs. 110/\$ 12

Growth of Firms in Indian Manufacturing Industry

N Shanta

CDS. 1994. pp 228, Hardcover, Rs. 250/ \$ 28

Demographic Transition in Kerala in the 1980s

K C Zachariah, S Irudaya Rajan, P S Sarma, K Navaneetham, P S Gopinathan Nair \& U S Mishra,

CDS. 1999 (2 ${ }^{\text {nd }}$ Edition) pp 305, Paperback, Rs.250/ \$ 28 
Impact of External Transfers on the Regional Economy of Kerala P R Gopinathan Nair \& P Mohanan Pillai

CDS 1994. pp 36, Paperback, Rs.30/ \$ 10

Urban Process in Kerala 1900-1981

T T Sreekumar

CDS. 1993. pp 86, Paperback, Rs.100/ \$ 11

Peasant Economy and The Sugar Cooperative: A Study Of The Aska Region in Orissa

Keshabananda Das

CDS. 1993. pp 146, Paperback, Rs.140/ \$ 16

Industrial Concentration and Economic Behaviour: Case Study of Indian Tyre Industry

Sunil Mani

CDS. 1993. pp 311, Hardcover, Rs. 300/ \$ 34

Limits To Kerala Model of Development: An Analysis of Fiscal Crisis and Its Implications.

K K George

CDS. 1999 ( $2^{\text {nd }}$ edition) pp 128, Paperback, Rs. 160/ \$ 18

Indian Industrialization: Structure and Policy Issues. (No Stock) Arun Ghosh, K K Subrahmanian, Mridul Eapen \& Haseeb A Drabu (EDs).

OUP. 1992. pp 364, Hardcover, Rs.350/ \$ 40

Rural Household Savings and Investment: A Study of Some Selected Villages

P G K Panikar, P Mohanan Pillai \& T K Sundari

CDS. 1992. pp 144, Paperback, Rs. 50/ \$ 10

International Environment, Multinational Corporations and Drug Policy

P G K Panikar, P Mohanan Pillai \& T K Sundari

CDS. 1992. pp 77, Paperback, Rs.40/ \$ 10

Trends in Private Corporate Savings

N Shanta

CDS. 1991. pp 90, Paperback, Rs. 25/ \$ 10 
Coconut Development in Kerala: Ex-post Evaluation

D Narayana, K N Nair, P Sivanandan, N Shanta and

G N Rao

CDS. 1991. pp 139, Paperback, Rs.40/ \$ 10

Caste and The Agrarian Structure

T K Sundari

Oxford \& IBH. 1991. pp 175, Paperback, Rs.125/ \$ 14

Livestock Economy of Kerala

P S George and K N Nair

CDS. 1990. pp 189, Hardcover, Rs. 95/ \$ 10

The Pepper Economy of India (No Stock)

P S George, K N Nair and K Pushpangadan

Oxford \& IBH. 1989. pp 88, Paperback, Rs. 65/ \$ 10

The Motor Vehicle Industry in India

(Growth within a Regulatory Environment)

D Narayana

Oxford \& IBH. 1989. pp 99, Paperback, Rs. 75/ \$ 10

Ecology or Economics in Cardamom Development (No Stock)

K N Nair, D Narayana and P Sivanandan

Oxford \& IBH. 1989. pp 99, Paperback, Rs. 75/ \$ 10

Land Transfers and Family Partitioning

D Rajasekhar

Oxford and IBH. 1988. pp 90, Hardcover, Rs. 66/ \$ 10

Essays in Federal Financial Relations

I S Gulati and K K George

Oxford and IBH. 1988. pp 172, Hardcover, Rs. 82/ \$ 10

Bovine Economy in India

A Vaidyanathan

Oxford \& IBH. 1988. pp 209, Hardcover, Rs. 96/ \$ 11

Health Status of Kerala

P G K Panikar and C R Soman

CDS. 1984. pp 159, Hardcover, Rs.100/ \$ 11 \& Paperback, Rs. 75/ \$ 10 
This work is licensed under a

Creative Commons

Attribution - NonCommercial - NoDerivs 3.0 Licence.

To view a copy of the licence please see:

http://creativecommons.org/licenses/by-nc-nd/3.0/ 